\title{
Tourism Crisis Management in Jordan: an Overview
}

\author{
Professor Sultan Nayef Abu Tayeh \\ School of Business/Department of Public Administration \\ University of Jordan; Amman, Jordan
}

\author{
Dr Mairna Hussein Mustafa \\ Queen Rania Faculty of Tourism and Heritage/ Department of Sustainable Tourism \\ Hashemite University; Zarqa, Jordan
}

\begin{abstract}
The Arab Spring had its negative effects on tourism in the region of the Middle East. This research note aims to make overview of strategies adopted by Jordanian Tourism Public Authorities to repair the image in time of crisis to bring back tourists; a short discussion is then made on political crisis management, which then was referred to in giving recommendations to enhance the performance of these authorities in dealing with such crisis.
\end{abstract}

Keywords: Political Crisis Management, Destination Image Repair, Strategic Management, Arab Spring, Tourism in Jordan

\section{BACKGROUND}

Since December 2010, revolutionary waves took place in the Arab world and were presented in the media as the "Arab Spring"; protests took place in Tunisia and Egypt and shortly after emerged in Middle Eastern region. Thousands of people seeking for better living conditions went into marches and strikes, after which the world witnessed the fall of presidents and drastic political and social instability as in Tunisia, Egypt, Libya and Yemen, while monarchies of Morocco and Jordan, which continued to be politically stable adopted gradual political reforms (Masetti \& Körner, 2013). There were significant influences on the economies of Middle East \& North Africa countries where deteriorations were recorded for economic indicators as GDP and employment (OECD, 2011) (See Figure 1). The effect was also witnessed in tourism industry; there was a decline in the volume of incoming tourists, tourism revenues, and hotels occupancy. Turkey, the countries of Eastern Europe and some Asian countries as Malaysia, Thailand, and Indonesia became alternatives to Arab countries as tourism destinations (Ali et. al. 2012). Jordan was one of the countries that suffered from such situation, many visitors from Europe and America cancelled their visits, there was a drop in the number of tourist arrivals from 8,078,380 in 2010 to 6,812,438 in 2011 (15.7\% decrease); while number of package tours decreased from 707,735 to 419,571 (Statistics of Ministry of Tourism \& Antiquities [MOTA], 2010/2011). 


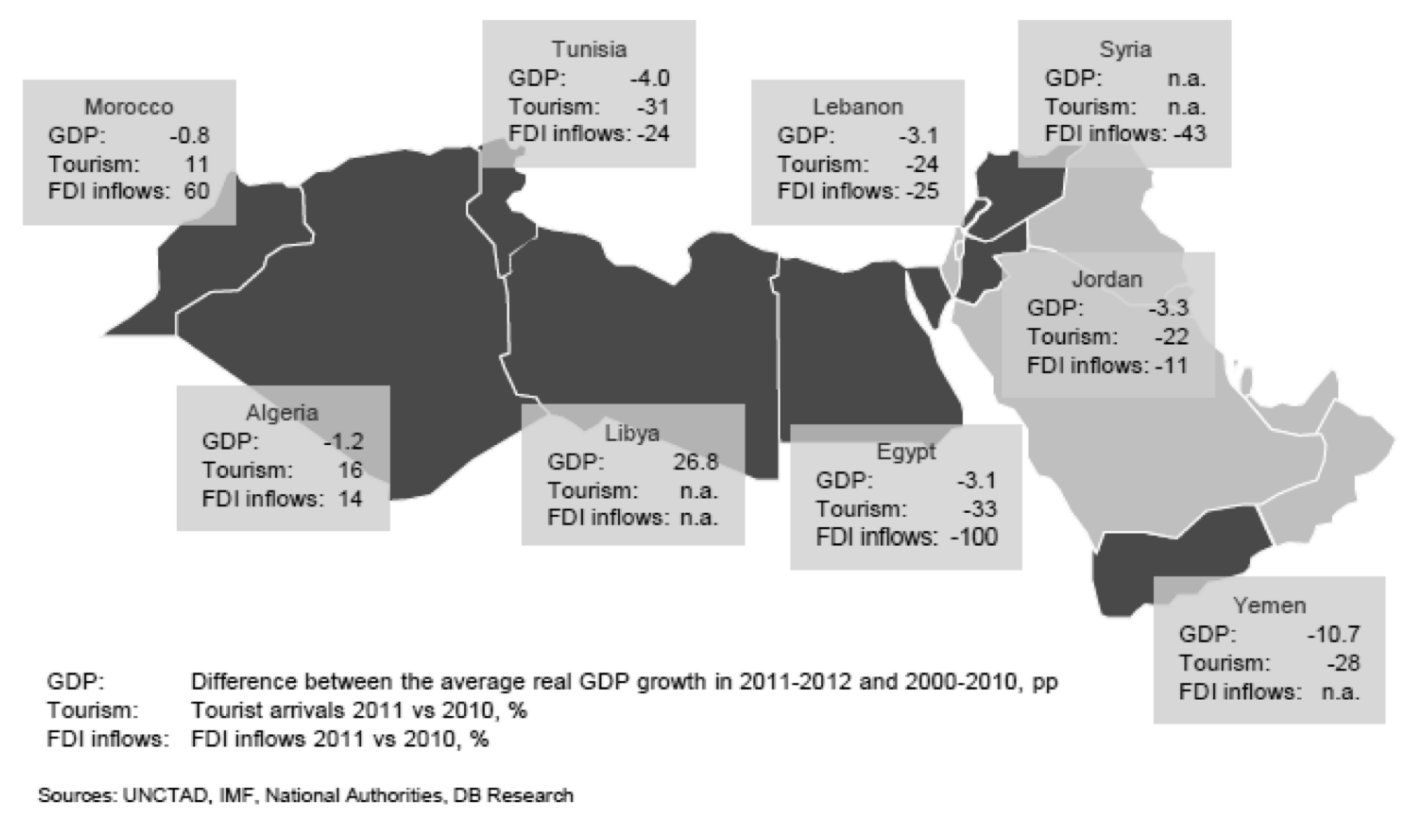

Figure 1: The economic impact of Arab Spring on different countries in MENA region (Masetti \& Körner, 2013)

\section{THE PROBLEM}

For Jordan, tourism is the largest export sector, its second private sector employer, and a major producer of foreign exchange (MOTA, 2003), it accounts for approximately $10.50 \%$ of the country's gross domestic product (GDP) (Central Bank of Jordan [CBJ], 2016). Tourism has generated 2870.9 million JD in 2016 as revenue (1 JD = 1.408 USD), while tourists expenditures reached 892.9 million JD during the same year (MOTA, 2016). Though, it can be said that the period 2010-2015 was a crisis time to Jordanian tourism, where different indicators of sector performance have shown a clear decline if compared to the period prior to 2010; by looking at the statistical reports of Jordanian Ministry of Tourism \& Antiquities for the years (2010-2016); Table 1 shows some of the main indicators for Jordanian tourism for the years (2010-2016).

Other changes could be seen in what relates to the characteristics of tourism markets; the revenues of tourism sector in 2016 were similar to those of 2015 despite the increase in the number of tourists, this is due to the changes in the origin of tourists, which then affected their spending habits. There was a drop of $10 \%$ in the number of tourists from the Gulf Council countries (particularly from Saudi Arabia, the source of largest portion of visitors, where economic procedures taken by the Saudi government to cut down expenses had its impact on travel decisions). The conflicts in other countries in the region caused drops in medical tourism, especially for patients from Sudan, Libya, Yemen and Iraq. Moreover, Jordan is facing the challenge of dealing with spillover effect caused by instability in surrounding countries, also the economic, political and social pressure caused by receiving big numbers of Syrian refuges (UNWTO, 2017). 
Table 1: The main indicators of tourism performance in Jordan for the years (2010-2016); Source: Statistics of Ministry of Tourism \& Antiquities [MOTA]

\begin{tabular}{|c|c|c|c|c|c|c|c|}
\hline & \multicolumn{9}{|c|}{ Indicators } \\
\cline { 2 - 8 } Year & Arrivals & $\begin{array}{c}\text { Receipts } \\
\text { JD } \\
\text { Million) }\end{array}$ & $\begin{array}{c}\text { No of } \\
\text { Package } \\
\text { Tourists }\end{array}$ & $\begin{array}{c}\text { No of } \\
\text { Overnight } \\
\text { Tourists }\end{array}$ & $\begin{array}{c}\text { No of } \\
\text { Same } \\
\text { Day } \\
\text { Tourists }\end{array}$ & $\begin{array}{c}\text { No Tourist } \\
\text { Nights }\end{array}$ & $\begin{array}{c}\text { Tourists } \\
\text { Expendi } \\
\text { tures } \\
\text { (JD } \\
\text { Million) }\end{array}$ \\
\hline 2010 & $8,078,380$ & 2545.2 & 707,735 & $4,557,024$ & $3,690,112$ & $5,301,639$ & $1,010.5$ \\
\hline 2011 & $6,812,438$ & 2431.5 & 419,571 & $3,959,651$ & $2,852,787$ & $4,638,399$ & 823.9 \\
\hline 2012 & $6,314,250$ & 2883.6 & 446,165 & $4,162,367$ & $2,151,883$ & $5,806,317$ & 811.9 \\
\hline 2013 & $4,136,928$ & 2212.2 & 307,348 & $3,022,192$ & $1,114,736$ & $4,970,581$ & 778.3 \\
\hline 2014 & $5,326,501$ & 3106.6 & 443,226 & $3,989,913$ & $1,336,501$ & $2,019,287$ & 810.7 \\
\hline 2015 & $4,811,352$ & 2886.1 & 300,970 & $3,763,150$ & $1,048,202$ & $1,125,159$ & 823.5 \\
\hline 2016 & $4,778,529$ & 2870.9 & 372,661 & $3,858,439$ & 920,020 & $4,894,237$ & 892.9 \\
\hline
\end{tabular}

This is not the only or the first political crisis for Jordanian tourism, the location of the country in the region of the Middle East, which is continuously witnessing a series of political turbulences, is exposing it to a misperception on being an unsafe destination, which is contrary to the actual situation where high levels of safety and security are prevailed in all parts of Jordan. Several events contributed to such condition; Palestinian Israeli conflict that began in the mid $20^{\text {th }}$ century, kidnapping of western tourists by tribesmen in Yemen, terrorism attacks on tourists during 1990s in Egypt, Gulf War 1990-1, Iraq War since 2003, and finally the events of Arab Spring (particularly the Syrian War since 2011), all of these events give the Middle East its image as a region full of conflicts, causing then fluctuations in the tourists' volumes.

Despite the fact that such events are not new to the country, no clear written plan or a holistic approach on how to deal with such crises was published by neither Jordanian Ministry of Tourism \& Antiquities or Jordan Tourism Board. It should be admitted though that many actions were taken to repair the country's image and recover the losses that took place by the decline of tourists' arrivals. Avraham (2015) stated that it's surprising to find that only few studies focused on managing tourism crises and crisis communication in the region of the Middle East, a great amount of accumulating knowledge worldwide on this issue could have been utilised to deal with the consequences of the current unrest by decision makers and marketers.

Most of the focus by Jordanian tourism authorities (Ministry of Tourism \& Antiquities [MOTA] and Jordan Tourism Board [JTB]) was on attracting new markets and expanding promotional campaigns to overcome the decreases in tourists' arrivals. This short paper aims at evaluating the policies taken Jordanian Tourism Authorities to deal with the crisis based on comparing these actions with selected published research on tourism crisis management.

\section{TOURISM CRISIS MANAGEMENT MODELS}

A crisis is "a change, which may be sudden or which may take some time to evolve, that results in an urgent problem that must be addressed immediately" (Efficiency Unit of Hong Kong, 2009). As cited by Andrianopoulos (2015), Mitroff divided crises into different categories; these are: economic (as market crashes and labor shortage), informational (loss of information), public (as theft and attacks), physical (as vandalism and violence), reputational, psychopathic (as terrorist attacks), and natural disasters (as earthquakes, floods and outbreak of diseases). As well known, crisis events are unpredictable, but they are not always unexpected; from this comes the importance of "crisis management" in which organizational or 
inter-organizational responses should be appropriately coordinated (Efficiency Unit of Hong Kong, 2009).

For the case of Jordanian tourism, the Arab Spring influence on this sector can be considered as a combination of different crises types, it's economic since a significant decrease was witnessed in both tourist arrivals and revenues; and reputational since it had dramatically resulted in the misperception of the country as an unsafe destination due to its location.

Not considering crises in strategic planning or preparing for them would make organizations vulnerable (Andrianopoulos, 2015). Crisis management "seeks to prevent or lessen the negative outcomes of a crisis and thereby protect the organization, stakeholders, and/or industry from damage" (Coombs, 1999, p. 4). As stated by Stocker (1997, p. 189) crisis management is all about: "the preparation and application of strategies and tactics that can prevent or modify the impact of major events on the company or organization". This makes such issue vital in the case of Jordan; even with taking multiple actions to attract markets and to promote the country as a safe destination to repair the image of the country, a clear strategic approach should be implemented and publically declared to different stakeholders to ensure effectiveness of any action taken by authorities. According to Avraham and Ketter's (2008); restoring a destination image requires applying a holistic model, where a preliminary analysis of the crisis, the place it occurred and the target audience should be conducted to help marketers decide on the right strategy to follow after defining goals, here a priority could be given to target audience, source of negative image and message itself; thus selecting the right techniques and channels to use. Unfortunately, such analysis were not considered (based on what is published by Jordanian tourism authorities) when launching its promotional campaigns.

Different models to deal with crises were proposed in literature; Mitroff (as cited in Wang et al., 2009) developed a useful framework for understanding organizational crisis management; the following stages take place: Signal Detection: where early signals of crises are identified and being responded to; Crisis Preparation: in which planning and preparation are conducted to generate plans, crisis communication strategies, and crisis management teams; Crisis Containment: where actions are taken to mitigate losses; Crisis Recovery in which operations are conducted to help stakeholders overcome the crisis; No Fault Learning: where review and assessment are done to learn from the experience; and finally Redesign: in this stage crisis management processes are subject to adjustment, and information is considered for dealing with future detection of any crises signals.

Faulkner (2001) produced a generic model for analyzing and developing tourism crisis management strategies; he put crisis management into the following phases: the pre-event phase where both contingency plans and assessment studies are developed, then prodromal phase where such plans need to be activated after the occurrence of the crises or disasters, in the emergency phase actions should be taken to protect people and property, while clear media communication takes place in the intermediate phase, this is then to be followed by rebuilding affected areas and infrastructure, and finally the resolution phase in which the whole crisis management process is evaluated. A media communication strategy is needed to ensure non dissemination of misleading information; this should be backed with systems to provide information on status of tourism services, also effective warning systems. Not less important is the preparation of response and recovery plans which are to be prepared and implemented by relevant actors, such plans should be disseminated to organization and communities, also to be continuously updated as fits the situations of crises. The recovery stage also requires that efforts should be devoted to reexamine threats and to re-conduct a 
SWOT analysis since it is a continuous improvement, which will ensure the presence of management alternatives and incremental enhancements in dealing with crises (Hill \& Jones 2001). Such procedures were investigated in literature, which confirmed the significance of implementing them in different situations (e.g. the need of implementing proactive crisis management (Hayes \& Patton, 2001; Retchie, 2004; Carlsen \& Liburd, 2008; Pforr \& Hosie, 2008), integrating crisis management with strategic planning processes (Bierman, 2003; Retchie, 2004; Evans \& Elphik, 2005), the need to develop a comprehensive research agenda and market recovery (Carlsen \& Liburd, 2008), role of the government in crisis management (Blake and Sinclair, 2003); Signal detection in tourism crisis (Paraskevas \& Altinay, 2013); importance of communication (Retchie et. al., 2004; Marianna, 2011), preparing detailed contingency plans (Evans \& Elphik, 2005), organizational learning and integration of stakeholders (Retchie et. al., 2004; Blackman \& Retchie, 2008; Marianna, 2011)). Different practical guidelines of how to manage a crisis were developed. The prime examples are those tourism crisis manuals published by the World Tourism Organization (WTO, 2003) and the Pacific Asia Travel Association (PATA 2003). For example, PATA handbook is widely employed by tourism practitioners, it provides a suggested framework to take action on risk and crisis management using the Four R's approach. Such approach shows how destinations and small businesses can effectively manage the four distinct phases of a crisis: Reduction, Readiness, Response and Recovery.

\section{DEALING WITH THE SITUATION}

Despite being started seven years ago, the tragic effects of Arab Spring are still witnessed, these are characterised by the influx of refugees, radicalization of youth and increased terrorism, and such effects are expected to continue in the next years (Rawashdeh, 2017). As for tourism sector; Jordanian tourism authorities declared taking some particular actions to deal with the decrease in the numbers of international tourists; one of these was putting an emergency plan as declared by Jordan Tourism Board (which was not formally published) to raise international profile of the country and to target markets as Gulf countries (Saudi Arabia and United Arab Emirates), Turkey and Far East (China, Japan and South Korea) (Jordan Times, 2015). Several online and offline campaigns were launched targeting French, British, and German markets with European tour operator partners, advertisements on TV channels, taxis, and billboards were spread. Jordan was also promoted as a film destination; "The Martian" movie for example featured Wadi Rum as Mars. Another tool used was the "Jordan Pass", which gives tourists the chance to access all major archaeological sites and museums while waiving entry visa fees for pass holders, which forms a single ticket. Visa fees were waived for groups and individual travelers visiting Jordan through tour operators with a minimum stay of two consecutive nights. Also, visa fees for all land borders were reduced, the departure tax for both Aqaba International Airport and Marka Civil Airport were waived (Oddone, 2015). Other tools used to deal with the crisis were through the formal website of Jordan Tourism Board, where access to several live streaming cameras gives the chance to experience views of distinguished locations; through videos, tourists are presented as witnesses on their experience in Jordan; writings of travel bloggers are also posted where they recommend Jordan as a travel destination (Jordan Tourism Board, 2017). Other actions taken included: agreements with charter flights firms by Jordan Tourism Board to bring weekly flights from Europe to Jordan, a (US\$52) million budget was allocated for marketing activities as diversification of marketing and promotion techniques/tools, targeting arrivals from new and more resilient markets, tourists were encouraged to share their experiences on social media with the hashtags \#love_Jordan or \#Share_Your_Jordan. "Jordan: A family destination" summer brochure was launched and distributed in airports and at border crossings. Other procedures included: encouraging private sector to offer alternative accommodation (e.g. bed and breakfast accommodation), improving tourism services in some historical sites, conducting IT training 
for small businesses to market themselves, and launching a new website - by the Jordan Hotels Association (JHA) to offer hotel reservations with minimal commissions (UNWTO, 2017). Moreover, authorities took the action of amending hotels' electricity tariffs into industrial tariffs, which cut their electricity bills by a significant amount (Oddone, 2015). That is in addition to organizing and participation in different cultural events and exhibitions (e.g. what is published at: Eturbonews, different dates).

\section{CONCLUSION}

What was clearly seen in the case of Jordanian tourism crisis (as stated in local and international media) is basically taking communication and containment actions to recover from drastic deterioration in tourism arrivals and revenues; unfortunately, no clear strategic planning approach nor a post-crisis research or SWOT were followed in deciding these actions.

The above brief discussion demonstrate that a proactive and comprehensive approach should be adopted by the Jordanian tourism authorities to incorporate crisis management planning into the formulation of overall national marketing/management strategies to rebuild their image of safety/attractiveness and to support enterprises of tourism industry in their economic recovery. There is an obvious absence of the concept of "Crisis Management" in tourism national strategies (MOTA, 2003; 2010; 2015); where there is a concentration in the first place on diversifying the tourism product, enhancing the image of the country, increasing competitiveness and development of human resources. Another important implementation is forming departments or special committees of different stakeholders to ensure their effective participation and contribution to solve the situation, especially that there is an obvious negative perception among Jordanians in tourism industry that authorities are not doing enough (Jordan Times, July 21, 2015).

\section{References}

Ali, A., Arifin, Z., Hasi, M. (2012). The Challenges of Tourism in the Countries of the Arab Spring Revolutions, Advances in Natural and Applied Sciences, 6(7), 1162-1171.

Andrianopoulos, A. (2015). Essential Steps for Crisis Management and Crisis Containment, available online at: http://www.acg.edu/ckeditor_assets/attachments/1568/essential_steps_for_crisis_management_and_crisis_cont ainment.pdf [Accessed 15 April 2017].

Avraham, E. (2015). Destination image repair during crisis: Attracting tourism during the Arab Spring uprisings, Tourism Management, 47, 224-232.

Avraham, E., \& Ketter, E. (2008). Media strategies for marketing places in crises: Improving the image of cities, countries, and tourist destinations. Oxford, England: Butterworth Heinemann.

Beirman, D. (2003). Restoring tourism destinations in crisis: A strategic marketing approach [online]. In: Braithwaite, Robyn L (Editor); Braithwaite, Richard W (Editor). CAUTHE 2003: Riding the Wave of Tourism and Hospitality Research. Lismore, N.S.W.: Southern Cross University.

Blackman, D. \& Ritchie, B. (2008). Tourism Crisis Management and Organizational Learning, Journal of Travel \& Tourism Marketing, 23, 2-4, 45-57.

Blake, A. and Sinclair, M. T., 2003. Tourism Crisis Management: US Response to September 11, Annals of Tourism Research, 30 (4), 813-832.

Carlsen, J. \& Liburd, J. (2008). Developing a Research Agenda for Tourism Crisis Management, Market Recovery and Communications, Journal of Travel \& Tourism Marketing, 23, 2-4, 265-276.

CBJ. (2016). The Annual Report 2016, the Central Bank of Jordan, available online at: http://www.cbj.gov.jo/Pages/viewpage.aspx?pageID=68 [Accessed 25 November 2017].

Coombs, W. T. (1999). Ongoing Crisis Communication: Planning, Managing, and Responding. Thousand Oaks, CA: Sage Publications.

Coombs, W.T. (2007), Ongoing Crisis Communication: Planning, Managing, and Responding, London: Sage. 
Darling, J.R. 1994. Crisis management in international business: keys to effective decision making, Leadership and Organization Development Journal, 15(8), 3-8.

Efficiency Unit in Hong Kong. (2009). Crisis Management- an international overview, available online at: http://www.eu.gov.hk/en/reference/publications/crisis_management.pdf [Accessed 15 April 2017].

Eturbonews, different dates. Several Articles on Tourism in Jordan after Arab Spring; available at: https://www.eturbonews.com/?s=Jordan+Arab+Spring

Evans, N. and Elphick, S. (2005), Models of crisis management: an evaluation of their value for strategic planning in the international travel industry. Int. Journal of Tourism Research, 7(3), 135-150.

Faulkner, B. (2001). Towards a framework for tourism disaster management, Tourism Management, 22 (2), 135147.

Faulkner, B. \& Vikulov, S. (2001) Katherine, washed out one day, back on track the next: a post-mortem of a tourism disaster, Tourism Management, 2, 331-344.

Fink, S. (1986), Crisis management: Planning for the Inevitable, New York: Amacom.

Glaesser, D. (2006). Crisis Management in the Tourism Industry (2nd ed.). Oxford: Butterworth, Heinemann.

Hayes, D., \& Patton, M. (2001). Proactive crisis-management strategies and the archaeological heritage, International Journal of Heritage Studies, 7(1), 37-58.

Hill, C. \& Jones, G. (2001). Strategic Management: an Integrated Approach, 5th edition, New York: Houghton Mifflin Harcourt.

Jordan Times. (2015). Jordan Battling to Rejuvenate Tourism Sector. Jordan Times, Issue of July 21, 2015, available online at: http://www.jordantimes.com/news/local/jordan-battling-rejuvenate-tourism-sector [Accessed 11 March 2016].

Jordan Tourism Board. (2017). The Official Website of Jordan Tourism Board, available online at: http://international.visitjordan.com [Accessed 25 December 2017].

Laws, E. \& Prideaux, B. (2006) Crisis management: A suggested typology. Journal of Travel and Tourism Marketing, 19(2-3), 1-8.

Mansfield, Y. \& Pizam, A. (Eds.) (2006). Tourism, Security and Safety. Oxford: Butterworth Heineman.

Marianna, S. (2011). Social Media and Crisis Management in Tourism: Applications and Implications for Research, Information Technology \& Tourism, 13(4). 269-283.

Masetti, O. \& Körner, K. (2013). Two years of Arab Spring: Where are we now? What's next? Series of Current Issues Emerging markets (January 25, 2013), Deutsche Bank.

MOTA. (2003). National Tourism Strategy (2004-2010), by Ministry of Tourism \& Antiquities, [Online] Available: http://www.tourism.jo/Contents/National_StrategiesAr.aspx [Accessed 25 November 2017].

MOTA. (2010). National Tourism Strategy (2011-2015), by Ministry of Tourism \& Antiquities and USAID/Jordan, [Online] Available: http://www.tourism.jo/Contents/National_StrategiesAr.aspx [Accessed 25 November 2017].

MOTA. (2015). Ro'ya al-Urdun 2025, by Jordanian Government, [Online] Available:

http://www.tourism.jo/Contents/National StrategiesAr.aspx [Accessed 25 November 2017].

MOTA. (2011-2016). Statistical Bulletins available on The Official Website of Ministry of Tourism and Antiquities, available online at: http://www.mota.gov.jo [Accessed 12 March 2017].

OCED. (2011). Socio-Economic Context and Impact of the 2011 Events in the Middle East and North Africa Region, MENA-OECD Investment Programme (December 2011). Available online at: http://www.oecd.org/mena/competitiveness//49171115.pdf [Accessed 11 March 2016].

Oddone, E. (2015). Bringing Them Back: Boosting Jordan's Ailing Visitor Numbers, available online at: http://www.venturemagazine.me/2015/12/bringing-them-back-boosting-jordans-ailing-visitor-numbers/ [Accessed 22 December 2017].

PATA. (2003). Crisis - it won't happen to us, Bangkok: The Pacific Asia Travel Association (PATA), available online at:

http://www.visitmyphilippines.com/images/ads/8140278ab0a66d6370c08941e16759dd.pdf [Accessed 11 March 2016]. 
Paraskevas, A. and Altinay, L. (2013). Signal Detection as the First Line of Defence in Tourism Crisis. Management, Tourism Management, 34(1), 158-171.

Pauchant, T.C. \& Mitroff, I. (2001). Transforming the crisis prone organization: preventing individual, organisational and environmental tragedies. San Francisco: Jossey-Bass.

Pearson, C and Mitroff, I. (1993), "From Crisis-Prone to Crisis-Prepared: A Framework for Crisis Management", Academy of Management Executive, 7(1), 48-59.

Pforr, Ch. (2006). Tourism in Post-Crisis is Tourism in Pre-Crisis: A Review of the Literature on Crisis Management in Tourism, Working Paper Series: no. 2006:1, Curtin University of Technology, School of Management.

Rawashdeh, S. (2017). Arab Spring is a Continuous Process- Jordanian Economist, Jordan Times, issue of 19 July 2017, available online at: http://jordantimes.com/news/local/arab-spring\%E2\%80\%99-continuousprocess\%E2\%80\%99-\%E2\%80\%94-jordanian-economist [Accessed 25 December 2017].

Ritchie, B. W. (2004) Chaos, crises and disasters: a strategic approach to crisis management in the tourism industry, Tourism Management, 25 (6), 669-683.

Seyondcott, N. \& Laws, E. (2006) Tourism crisis and disasters: Enhancing understanding of system effects, Journal of Travel and Tourism Marketing, 19(2-3), 149-158.

Smith, D. and Elliott, D. (2006), Key Readings in Crisis Management systems and structures for prevention and recovery, New York: Routledge.

Sönmez, S., Apostolopoulos, Y., \& Tarlow, P. (1999). Tourism in Crisis: Managing the Effects of Terrorism, Journal of Travel Research, 38(1), 13-18.

Stocker, K. (1997). A Strategic Approach to Crisis Management. In C.L. Caywood (Ed): The Handbook of Strategic Public Relations and Integrated Communications. (pp 189-203), New York: McGraw-Hill.

UNWTO. (2017). Al Multaqua Ballroom, Arabian Travel Market (ATM), Dubai, Monday, 24 April 2017, Forty second meeting, UNWTO Commission for the Middle East, available online at: http://middleeast.unwto.org/event/42nd-meeting-unwto-commission-middle-east [Accessed 25 December 2017].

Wang, J., Hutchins, H. M., \& Garavan, T. (2009). Exploring the strategic role of HRD in organizational crisis management. Human Resource Development Review, 8(1), 22-53.

WTO (2003). Crisis Guidelines for the Tourism Industry. Madrid: World Tourism Organization. 